\title{
The effect of sewage sludge on the growth and species composition of the sward and the content of heavy metals in plants and urban soil
}

 \\ URSZULA WYDRO $^{1}$, TADEUSZ ŁOBODA ${ }^{1}$, ANDRZEJ BUTAREWICZ ${ }^{1}$ \\ ${ }^{1}$ Division of Sanitary Biology and Biotechnology, Bialystok University of Technology \\ ${ }^{2}$ Department of Environmental Improvement, Warsaw University of Life Sciences - SGGW
}

\begin{abstract}
The effect of sewage sludge on the growth and species composition of the sward and the content of heavy metals in plants and urban soil. The determination of the sludge fertilising influence for the growth and composition of the urban grasslands' swards and heavy metals concentration in above-ground parts of the plants was the aim of the study. The study was conducted on four

in the study allowed for estimating the plants ability to collect heavy metals present in the soil. Based on these results, it was found that the rate of bioconcentration of $\mathrm{Cd}, \mathrm{Cr}, \mathrm{Cu}$ and $\mathrm{Pb}$ was the highest in August, which may indicate the ease of downloading these metals by plants, particularly high mobility of metals during this period, and lower in October and June.
\end{abstract} research plots along the main roads in Białystok. The plots were seeded with two mixtures of lawn grasses (Eko and Roadside) and three doses of sludge were applied: 0 (control), 7.5 and $15 \mathrm{~kg} / \mathrm{m}^{2}$. The study also included the determination of concentrations of $\mathrm{Cd}, \mathrm{Cr}, \mathrm{Cu}, \mathrm{Pb}$ and $\mathrm{Zn}$ in soil and in the above-ground parts of lawn grasses and selected physical and chemical properties of soils fertilized with different doses of sludge. The dose of $7.5 \mathrm{~kg} / \mathrm{m}^{2}$ increased the plant dry matter on average by $53 \%$, the dose of $15 \mathrm{~kg} / \mathrm{m}^{2}$ - on average by $90 \%$. The largest effect of fertilization was found for lightest soil. Under these conditions, grass dry matter fertilized with $7.5 \mathrm{~kg} / \mathrm{m}^{2}$ sludge was almost doubled, and fertilized with the dose of $15 \mathrm{~kg} / \mathrm{m}^{2}$ was almost three times larger than in not fertilized areas. Perennial ryegrass (Lolium perenne L.) was the dominant species in the sward. Perennial ryegrass constituted on average $71 \%$ of all grass species in the areas fertilized with sewage sludge in the dose of $7.5 \mathrm{~kg} / \mathrm{m}^{2}$, while on the areas fertilized with $15 \mathrm{~kg} / \mathrm{m}^{2}$ - about $81 \%$, and on not fertilized ones $-50 \%$ on average. Bioconcentration factor

Key words: sewage sludge application, lawn grasses, biomass, roadsides

\section{INTRODUCTION}

City green areas, including lawns, have multiple functions. On the one hand, well-kept lawns enhance the aesthetic value of the city, on the other hand, they act as a cleansing (phytoremediation), both of air and soil. The pollutants from transport influence the natural environment as a whole and thus have a negative impact on the human beings (Gawroński 2009). As a result of fuel combustion in engines and tear of the tires and other parts of vehicles, the following substances get into the air: carbon monoxide, nitrogen oxides, hydrocarbons, including polycy- 
clic aromatic hydrocarbons, particulate matter and heavy metals (Badyda 2010).

Grassy areas in the passageways are usually established on degraded soils characterized by a mechanical malfunction and poor trophic conditions. Before the introduction of plants or at the stage of change of land use, soils often require the enrichment of organic substance source of macro- and micronutrients intended to improve the physical and chemical properties and to accelerate positive biological changes (Karczewska et al. 2012).

Proper compactness of urban green space requires such a choice of plants which will have ecological, technical and aesthetic functions. Grasses growing on the street areas should have the following characteristics: the ability to absorb heavy metals from the soil, resistance to soil salinity and winter conditions, the ability to increase compactness grow quickly and the permanently tracks of land and resilient, and the resistance to kneading aligned turf (Brede 2000, Pawluśkiewicz 2009). Approximately 160 species of grasses occur in Poland, but only 16 are suitable for lawns. The commonly used species of lawn grasses are the following: red fescue (Festuca rubra L.), Kentucky bluegrass (Poa pratensis L.) and perennial ryegrass (Lolium perenne L.) - Jankowski et al. 2012. Variations of these lawn grasses form grass of a good technical and aesthetic quality, due to the rapid and uniform germination after sowing, fast and good propagation and slow regrowth, durability, long growing season and resistance to unfavorable conditions for development and growth. Adding perennial ryegrass to grass mixtures allows quick installation and maintaining the compact and elastic turf, while including Kentucky bluegrass - the durability and greater resistance to mechanical damage turf, whereas adding red fescue to grass mixtures - an increase in resilience to unfavorable habitat conditions and weather (Pawluśkiewicz 2009).

Sewage sludge, as a by-product of wastewater treatment, is becoming an increasing ecological and economical problem. From year to year in Poland and other European Union (EU) countries the amount of municipal sewage sludge is increasing, what is associated with the dynamic expansion of the sewerage network. According to Directive 2008/98/EC (2008), the total amount of sewage sludge produced in the EU is expected to reach 13 million tons in 2020 , being $44 \%$ of this recycled to land. This situation makes necessary to look for new methods and ways of its rational use. One of the ways of disposing of sewage sludge is to use it for the purpose of rehabilitation of degraded land, biological fixation of soil surface from wind or water erosion or improvement of water retention or any fertilizing plants not intended for human consumption (Clarke and Smith 2011). According to Siuta and Wasiak (2001), the sludge seems to be effective recultivation material. It has great fertilizing and soil formative potential. The development of a method of using sewage sludge to improve the growth and development of grasses for compactness in urban areas would contribute to the improvement of the quality of urban green areas and street-adjacent areas would be a good place for application of these deposits. Although raw sewage sludge contains 
valuable nutrients, such as nitrogen, phosphorus, organic matter and essential trace elements, it also contains various toxins, especially heavy metals, which cause harm to the soil - plant system and further might pose a serious risk to human health (Pathak et al. 2009). According to Singh and Agrawal (2008), the bioavailability of metals brought to precipitate into the soil is determined by the properties of soil, such as $\mathrm{pH}$, organic matter content, redox potential, as well as the size of the applied dose of sludge. Some metals due to the different nature of the physical/chemical properties may show affinity to the other components of sewage sludge and soil, to which they are added (Kazimierczak 2012).

The aim of the study was to determine the effect of fertilization with municipal sewage sludge from the Municipal Sewage Treatment Plant in Sokółka on the growth and species composition of the sward of lawn grass varieties and the content of heavy metals in above-ground parts of plants and urban soil.

\section{MATERIAL AND METHODS}

The study was conducted in four places in Białystok. The experiment was established in Autumn 2010 in a randomized block design (on plots of $5 \mathrm{~m}^{2}$ ) and was carried out during the growing season of 2011. The study included the following research factors:

A.The three given doses of the sludge shown below were applied to the test areas and mixed with the $20 \mathrm{~cm}$ of upper layer of soil:

- without fertilization (control),

- fertilization at a dose of $7.5 \mathrm{~kg}$ per $1 \mathrm{~m}^{2}$,
- fertilization at a dose of $15 \mathrm{~kg}$ per $1 \mathrm{~m}^{2}$.

B. The habitat conditions of grassy area locations (Table 1):

- Popiełuszki Str. - green belt on a two-lane carriageway in the city center,

- Hetmańska Str. - two-lane carriageway road junction on the outskirts,

- Piastowska Str. - single lane carriageway outskirts,

- Raginisa Str. - shoulder of one-lane road on the outskirts of the city (housing estate area).

C. In the experiment two grass mixtures were used:

- Eko - from Nieznanice (PL) Plant Breeding Station composed of 30\% of Lolium perenne cv. Niga, $15 \%$ of Poa pratensis cv. Amason, 22.6\% of Festuca rubra cv. Adio and 32.4\% of Festuca rubra cv. Nimba,

- Roadside - from Barenbrug composed of $32 \%$ of Lolium perenne cv. Barmedia, $5 \%$ of Poa pratensis cv. Baron, $52 \%$ of Festuca rubra rubra cv. Barustic, 5\% of Festuca rubra commutata cv. Bardiva (BE) and $6 \%$ of Festuca rubra commutata cv. Bardiva (NL).

Each combination was performed in triplicate to obtain 72 experimental plots.

Before the establishment of the experiment both sewage sludge and soil samples from each combination were analysed according to the regulation of Minister of the Environment from 2010 (Rozporządzenie... 2010) concerning municipal sewage sludges, shown in Table 1 . The chemical and physical analyses were done by the Regional Chemical and Agricultural Station in Białystok. Additionally, twice in season $\mathrm{pH}$ of the soil was measured in $1 \mathrm{M} \mathrm{KCl}$. 
TABLE 1. Some physical and chemical properties of the soil surface $(20 \mathrm{~cm})$ without sludge

\begin{tabular}{|c|c|c|c|c|c|c|c|c|c|c|}
\hline \multirow{2}{*}{ Street } & \multirow{2}{*}{$\begin{array}{c}\text { Sand } \\
(\%)\end{array}$} & \multirow{2}{*}{$\begin{array}{l}\text { Silt } \\
(\%)\end{array}$} & \multirow{2}{*}{$\begin{array}{l}\text { Clay } \\
(\%)\end{array}$} & \multirow{2}{*}{$\mathrm{pH}$} & \multirow{2}{*}{ Soil texture } & \multirow{2}{*}{$\begin{array}{l}\mathrm{C}_{\text {org }} \\
(\%)\end{array}$} & \multirow{2}{*}{$\begin{array}{c}\mathrm{N} \\
(\%)\end{array}$} & $\mathrm{P}_{2} \mathrm{O}_{5}$ & $\mathrm{~K}_{2} \mathrm{O}$ & \multirow{2}{*}{$\begin{array}{c}\mathrm{EC} \\
(\mu \mathrm{S} / \mathrm{cm})\end{array}$} \\
\hline & & & & & & & & \multicolumn{2}{|c|}{$(\mathrm{mg} / 100 \mathrm{~g})$} & \\
\hline Hetmańska & 76 & 22 & 2 & 7.9 & loamy sand & 1.6 & 0.3 & 7.3 & 6.4 & 184.0 \\
\hline Piastowska & 72 & 25 & 3 & 7.7 & sandy loam & 1.6 & 0.3 & 18.4 & 7.9 & 213.9 \\
\hline Popiełuszki & 76 & 22 & 2 & 7.4 & loamy sand & 2.0 & 0.4 & 22.0 & 14.0 & 202.5 \\
\hline Raginisa & 84 & 15 & 1 & 7.4 & sand & 1.7 & 0.3 & 10.0 & 5.8 & 201.4 \\
\hline
\end{tabular}

Sewage sludge used in experiment contained: dry matter $-19.3 \%$, organic matter $-584 \mathrm{~g} / \mathrm{kg}$ d.m., $\mathrm{N}-40 \mathrm{~g} / \mathrm{kg}$ d.m., $\mathrm{P}-27 \mathrm{~g} / \mathrm{kg}$ d.m., $\mathrm{Mg}-7 \mathrm{~g} / \mathrm{kg}$ d.m., $\mathrm{Pb}$ $-23.5 \mathrm{mg} / \mathrm{kg}$ d.m., $\mathrm{Cd}-<0.5 \mathrm{mg} / \mathrm{kg}$ d.m., $\mathrm{Cr}-58 \mathrm{mg} / \mathrm{kg}$ d.m., $\mathrm{Cu}-194 \mathrm{mg} /$ /kg d.m., Ni - 22, Zn - 1,459 mg/kg d.m. and its $\mathrm{pH}$ was 6.7 .

In October 2011 the samples of soil $(0-20 \mathrm{~cm})$ were collected. Heavy metals concentrations in soils with sewage sludge and in plant material were determined by use of Atomic Absorption Spectrometry (AAS). The samples of soil were mineralized in temperature at about $450^{\circ} \mathrm{C}$ and remains were dissolved in aqua regia $(3: 1$ mixture of $\mathrm{HCl}$ and $\mathrm{HNO}_{3}$ ) at $80^{\circ} \mathrm{C}$ (PN-ISO 11047:2001). The samples of mixtures of grasses were mineralized in temperature at about $450^{\circ} \mathrm{C}$ and remains were dissolved in concentrated $\mathrm{HNO}_{3}$ (Filipka et al. 2002).

The determination of particle size was done by the Casagrande areometric method modified by Prószyński, which embraces measuring the density of soil suspension during progressive sedimentation of soil particles at a constant temperature. Density measurements were made with the Prószyński hydrometer, and the density of the soil suspension was checked in the periods indicated in the tables developed by Prószyński. This procedure is regulated by the
PN-R-04032 standard published mostly for agricultural soil analysis. Additionally, two times in the season $\mathrm{pH}$ of the soil was measured in $1 \mathrm{M} \mathrm{KCl}$.

Plants for the dry matter determination were taken every 4 weeks during the growing season, afterwards they were dried in an oven at $105^{\circ} \mathrm{C}$ for $24 \mathrm{~h}$, and then at $75^{\circ} \mathrm{C}$ until water evaporated completely. Bioconcentration factors for analyzed heavy metals were determined as quotients of average concentration of a given element in plants with relation to their average concentration in soil (Kabata-Pendias and Pendias 1999). The botanical composition of the vegetation was specified by means of a detailed botanical analysis. Sown plant species, alien species (not seeded) and dead plants were selected from plants collected at the end of the growing season and dried at $105^{\circ} \mathrm{C}$. The dry weight of each species was determined and referred to the total dry weight of the biomass collected by expressing the separated species of plants as a percentage.

The correlation between heavy metals concentration in above-ground parts of plants and in soil fertilized with different doses of sewage sludge were calculated by use of Pearson's correlation factor $r$ for $p \leq 0.05$ by using Statistica 10.0. The dry weight and the composition of the sward of grass species were evalu- 
ated statistically based on the analysis of variance (ANOVA) in the Statgraphics Plus, at a significance level $\alpha=0.01$ in the Tukey test.

\section{RESULTS AND DISCUSSION}

The urban soil is usually formed from municipal construction landfill, which means that its structure is dense, it has a low content of humus, low water content, low water permeability (Greinert 2000), as well as it is exposed to various types of risks in connection with the still evolving industries and transport (Rajkumar 2013). Therefore, the sludge may be a good nutrient base for grasses, grown on urban soils (Singh and Agrawal 2008), which gradually releases the nutrients profitable for growth of perennial crops
(Greinert 2000). Biomass production, as reported by Starck (2006), is mainly due to the activity of photosynthesis and nitrogen assimilation, which activates the processes of growth, reflected, among other things, by the increase in leaf assimilation area and good tillering (Olszewska et al. 2008). In our study, it was found that biomass of plants growing on the sidewalk grassy surfaces mainly depends on the dose of the sludge. Habitat conditions and the type of grass mixtures influence the size of the biomass in smaller extent (Table 2).

With increasing doses of sewage sludge biomass of plants was growing. The dose of $7.5 \mathrm{~kg} / \mathrm{m}^{2}$ increased the size of the average dry weight by $53 \%$, a dose of $15 \mathrm{~kg} / \mathrm{m}^{2}$ - on average by $90 \%$. The effectiveness of fertilization depended

TABLE 2. Dry matter of the aerial parts of plants fertilized with sewage sludge, depending on the dose, location, and a mixture of grasses

\begin{tabular}{|c|c|c|c|c|c|c|}
\hline \multirow{3}{*}{ Grass mixtures } & \multirow{3}{*}{$\begin{array}{c}\text { Dose } \\
\text { of sewage } \\
\text { sludge } \\
\left(\mathrm{kg} / \mathrm{m}^{2}\right) \\
\end{array}$} & \multicolumn{4}{|c|}{ Localization of experiment } & \multirow{3}{*}{ Means } \\
\hline & & Hetmańska & Piastowska & Popiełuszki & \multirow[t]{2}{*}{ Raginisa } & \\
\hline & & \multicolumn{3}{|c|}{ dry matter $\left(\mathrm{g} / \mathrm{m}^{2}\right)$} & & \\
\hline \multirow{3}{*}{$\frac{8}{|I|}$} & 0.0 & 363.3 & 493.1 & 320.8 & 343.9 & 380.3 \\
\hline & 7.5 & 622.8 & 828.8 & 436.5 & 528.6 & 604.2 \\
\hline & 15.0 & 688.1 & 888.5 & 554.6 & 764.1 & 723.8 \\
\hline \multirow{3}{*}{ 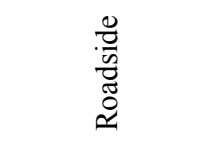 } & 0.0 & 413.0 & 543.4 & 344.0 & 306.4 & 401.7 \\
\hline & 7.5 & 595.1 & 786.5 & 499.4 & 505.0 & 596.5 \\
\hline & 15.0 & 640.4 & $1,009.7$ & 675.4 & 679.9 & 751.3 \\
\hline \multicolumn{7}{|l|}{ LSD } \\
\hline \multicolumn{2}{|c|}{ A-dose of sewage sludge } & \multicolumn{2}{|c|}{$16.14^{* *}$} & $32.43 * *$ & $14.68 * *$ & $21.32 * *$ \\
\hline \multicolumn{2}{|l|}{$\mathrm{B}$ - area } & \multicolumn{2}{|c|}{$25.22 * *$} & $50.69^{* *}$ & $22.93 * *$ & $33.32 * *$ \\
\hline \multicolumn{2}{|c|}{$\mathrm{C}$ - grass mixtures } & \multicolumn{2}{|r|}{$\mathrm{ns}$} & ns & $9.69 *$ & ns \\
\hline \multicolumn{2}{|c|}{$\mathrm{A} \times \mathrm{B}$} & \multicolumn{2}{|c|}{$57.88 * *$} & $\mathrm{~ns}$ & $\mathrm{~ns}$ & $\mathrm{~ns}$ \\
\hline \multicolumn{2}{|c|}{$\mathrm{A} \times \mathrm{C}$} & \multicolumn{2}{|r|}{ ns } & ns & $\mathrm{ns}$ & ns \\
\hline \multicolumn{2}{|c|}{$\mathrm{B} \times \mathrm{C}$} & \multicolumn{2}{|r|}{$\mathrm{ns}$} & ns & ns & ns \\
\hline
\end{tabular}

** - significant at $\alpha=0.01 ;$ - significant at $\alpha=0.05$; ns - not significant. 
TABLE 3. The botanical composition of street lawns fertilized with sewage sludge, depending on the dose, location, and mixture of grasses

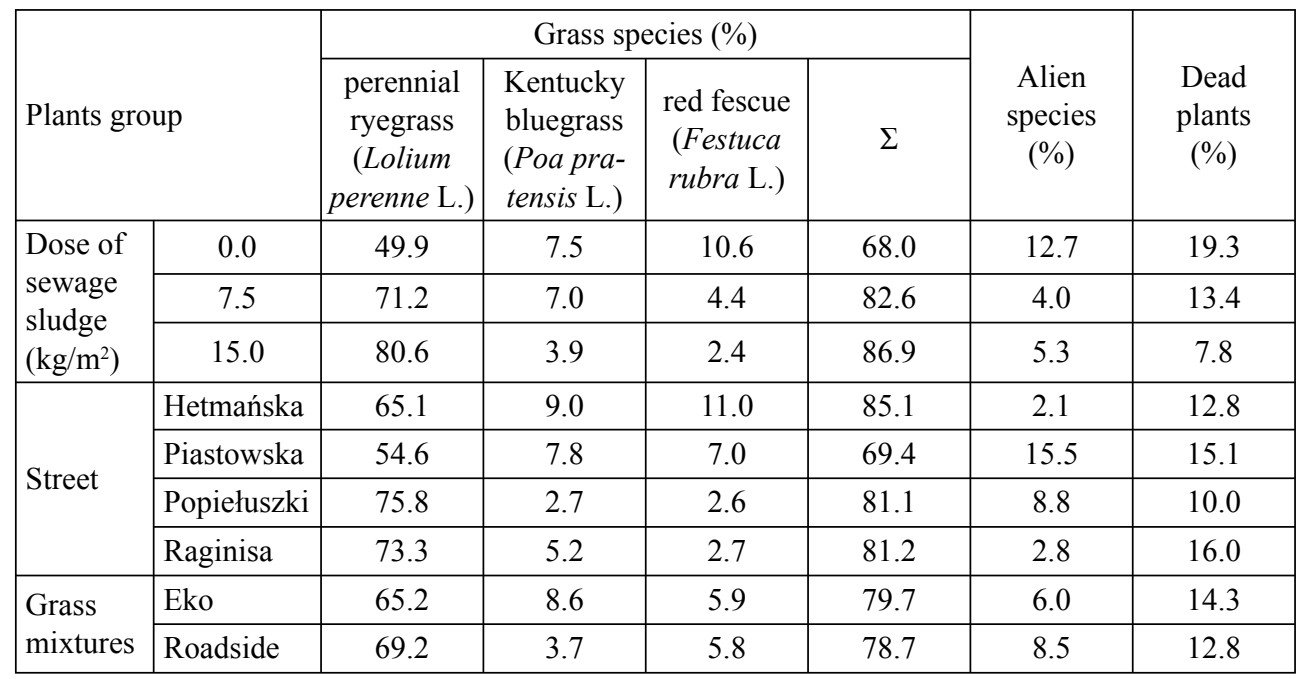

on the location of the lawns. The largest effect of fertilization was found for the lightest soil in the plots on Raginisa Street. Under these conditions, dry matter of plants fertilized with $15 \mathrm{~kg} / \mathrm{m}^{2}$ was almost doubled, and with the dose of $7.5 \mathrm{~kg} / \mathrm{m}^{2}$ was almost $58 \%$ bigger than in areas not fertilized. In the other habitats significantly larger mass was found after the application of the highest dose of sludge. In the plots on Piastowska and Hetmańska Streets, the effect of fertilization at a dose of $15 \mathrm{~kg} / \mathrm{m}^{2}$ was almost twice larger than on a mixture of Eko. Roadside mixture at the highest applied dose of fertilizer increased dry matter twice in the plots on Popiełuszki Street, while by approximately $50 \%$ on the plots on Hetmańska Street. The dose of $7.5 \mathrm{~kg} / \mathrm{m}^{2}$ contributed significantly to the growth of biomass in all analysed areas. The largest above-ground mass under these conditions was found in the areas with less anthropopressure (on the plots on Hetmańska Street). The dry weight on the aerial parts of the mixture Eko was there about $77 \%$ larger than under control conditions (Table 2). Many authors (Siuta and Wasiak 2001, Singh and Agrawal 2008, Gondek 2012) confirm the role of sewage sludge. As pointed by Gondek (2012), the amount of produced plant biomass and its chemical composition are strongly modified not only as a result of fertilization, but also as a result of changes of organic compounds in the soil, which in turn depend on the often changing environmental factors. The location of experimental plots in the city, along high traffic routes, is associated with high emissions from cars and other urban pollution, which may adversely affect the accumulation of plant biomass (Greinert 2000).

According to Grabowski et al. (1999), turf density is a trait that determines the value in use of species and varieties of lawn grasses. Rational use of grass is 
closely associated with a proper choice of species and varieties based on their morphological, biological and habitat requirements and on the applied treatments. In authors' study, the botanical composition of street lawns depended mainly on the dose of sewage sludge and its location (Table 3).

The participation of sown species in grass mixtures fertilized with $7.5 \mathrm{~kg} / \mathrm{m}^{2}$ of sewage sludge was $83 \%$ on average, and with a dose of $15 \mathrm{~kg} / \mathrm{m}^{2}-87 \%$ and it was higher by 15 and $19 \%$ respectively than that in the not fertilized grass mixtures. Lush growth of perennial ryegrass (Lolium perenne L.) determined the growth of the sown species in lawns. On the soil fertilized with a dose of $7.5 \mathrm{~kg} / \mathrm{m}^{2}$ perennial ryegrass constituted on average $71 \%$, in that fertilized with a dose of $15 \mathrm{~kg} / \mathrm{m}^{2}$ - about $81 \%$, while on those not fertilized $-50 \%$ on average. According to Domański and Golińska (2003), perennial ryegrass is one of the most often used species for establishing lawns. Lawn cultivars of this species develop quickly after sowing, increase the turf density, are relatively resistant to treading and obtain good values of turf compactness in the case of frequent cutting (Czarnecki and Harkot 2002). The participation of red fescue decreased with increasing doses of sludge on average from 11 to $2 \%$. The contribution of alien species on lawns fertilized with sewage sludge was significantly reduced (on average from 13 to $4 \%$ ) as a result of better development mainly of perennial ryegrass. The habitat conditions modified the contribution of the selected groups of plants. Seeded species, especially perennial ryegrass, developed the least on sandy loam, of a lower fertil- ity - on the plots on Piastowska Street (Table 3). According to Raper and Johnson (1995), turf is a system that requires constant human intervention by receiving a certain amount of biomass, such as in the process of cutting dead plants, so that the development of new ones would not be inhibited. Otherwise, some species disappear and areas without grass are formed or undesirable plant species appear. On the research surveyed plots without fertilization with sewage sludge a large share of alien species (on average $12 \%$ ) were observed, while with the highest fertilization with sewage sludge the contribution of alien species was only $5.3 \%$.

As a result of the discharge from the seasonal dying of whole plants, metals absorbed previously from the soil and from the air penetrate back into the soil environment, and thus they re-enrich soil. They become more available and more mobile than the metals present in the soil solution, and they can be re-absorbed by the plant (Perronnet et al. 2000). Among the physico-chemical properties of the soil, which determine the availability of metals to plants, one can distinguish the particle size, $\mathrm{pH}$ and organic matter content (Kabata-Pendias and Pendias 1999). The $\mathrm{pH}$ is an important factor determining the solubility of heavy metals in the soil on which, among others, ion balance depends - sorption and desorption processes of hydrogen cations and metal cations. Solubility of heavy metals is generally low in the neutral and alkaline conditions, and it increases with decreasing $\mathrm{pH}$ (Kabata-Pendias and Pendias 1999, Fuentes et al. 2004). Authors found that throughout the growing season soil $\mathrm{pH}$ on all test plots ranged on average 
from 7.15 to 7.48 , which means that at any point the soil was alkaline and at the highest dose of sludge $\mathrm{pH}$ of the soils, on which two analysed Eko and Roadside lawn grass mixtures were grown, had the lowest values - respectively 7.20 and 7.15 (Table 4). The analysis showed a significant inversely proportional negative correlation with $\alpha<0.05$ between $\mathrm{pH}$ in $1 \mathrm{M} \mathrm{KCl}$ and content of $\mathrm{Cu}$ and $\mathrm{Zn}$ in mixture of grasses - respectively $r=-0.47$ and $r=-0.42$. In the case of soil samples there was also a significant negative correlation between the content of zinc, chromium and copper in the soil and $\mathrm{pH} \mathrm{KCl}-$ respectively $\mathrm{r}=-0.67$, $r=-0.43$ and $r=-0.64$ (Table 5).

The study shows that the soil in urban areas is characterized by a very low content of C-organic. The application of sewage sludge increased the $\mathrm{C}_{\text {org }}$ on the plots and at a dose of $15 \mathrm{~kg} / \mathrm{m}^{2}$ it was almost twice as large as that on the area without sewage sludge (Table 4). The correlation analysis showed that the $\mathrm{C}_{\text {org }}$ contents in the soil was significantly positively correlated with the content of $\mathrm{Zn}$ in plants $(\mathrm{r}=0.56)$ and negatively with $\mathrm{Pb}$ content in plants $(\mathrm{r}=-0.44)$ at $\mathrm{p} \leq 0.05$ (Table 5).

TABLE 4. Selected physical and chemical properties of soils fertilized with different doses of sludge on which two grass mixtures were grown

\begin{tabular}{|l|c|c|c|c|c|c|}
\hline \multirow{3}{*}{ Parameters } & \multicolumn{7}{|c|}{ Grass mixtures } \\
\cline { 2 - 7 } & \multicolumn{7}{|c|}{ Eko } & \multicolumn{3}{c|}{ Roadside } \\
\cline { 2 - 7 } & 0.0 & 7.5 & 15.0 & 0.0 & 7.5 & 15.0 \\
\cline { 2 - 7 } & 7.5 & 7.3 & 7.2 & 7.3 & 7.3 & 7.1 \\
\hline $\mathrm{pH}$ & 63.7 & 60.5 & 62.7 & 60.7 & 57.7 & 57.0 \\
\hline Sand (\%) & 25.2 & 28.0 & 28.2 & 28.2 & 31.0 & 30.7 \\
\hline Silt (\%) & 11.0 & 11.5 & 9.0 & 11.0 & 11.2 & 12.2 \\
\hline Clay (\%) & 1.3 & 1.7 & 2.2 & 1.3 & 1.9 & 2.0 \\
\hline $\mathrm{C}_{\text {org }}(\%)$ & & & & & & \\
\hline
\end{tabular}

TABLE 5. Coefficients of correlation between the soil properties $(\mathrm{pH}$, granulometric parameters and organic carbon and total content of heavy metals in the soil and grass mixtures at the end of the experiment

\begin{tabular}{|l|c|c|c|c|c|c|c|c|c|c|c|}
\hline \multirow{2}{*}{ Parameters } & \multicolumn{4}{|c|}{ Soil } & \multicolumn{5}{c|}{ Grass mixtures } & \multirow{2}{*}{$n$} \\
\cline { 2 - 13 } & $\mathrm{Cd}$ & $\mathrm{Cr}$ & $\mathrm{Cu}$ & $\mathrm{Pb}$ & $\mathrm{Zn}$ & $\mathrm{Cd}$ & $\mathrm{Cr}$ & $\mathrm{Cu}$ & $\mathrm{Pb}$ & $\mathrm{Zn}$ & \\
\hline $\mathrm{pH}$ & -0.33 & $-0.43^{*}$ & $-0.67^{*}$ & -0.29 & $-0.64^{*}$ & -0.14 & -0.16 & $-0.47^{*}$ & 0.24 & $-0.42^{*}$ & 72 \\
\hline Sand & -0.04 & $-0.58^{*}$ & $-0.85^{*}$ & $-0.47^{*}$ & $-0.76^{*}$ & -0.34 & 0.08 & $-0.61^{*}$ & 0.20 & -0.38 & 72 \\
\hline Silt & 0.04 & $0.53^{*}$ & $0.85^{*}$ & $0.48^{*}$ & $0.77^{*}$ & 0.25 & -0.14 & $0.54^{*}$ & -0.30 & 0.33 & 72 \\
\hline Clay & 0.05 & $0.62^{*}$ & $0.73^{*}$ & 0.36 & $0.64^{*}$ & $0.52^{*}$ & 0.07 & $0.68^{*}$ & 0.07 & $0.47^{*}$ & 72 \\
\hline $\mathrm{C}_{\text {org }}$ & 0.19 & 0.18 & 0.28 & 0.003 & 0.31 & 0.11 & -0.01 & 0.27 & $-0.44^{*}$ & $0.56^{*}$ & 72 \\
\hline
\end{tabular}


The properties of the soil, arising from its particle size examined for individual streets and grass mixture, were indeed correlated with the metal concentrations in the soil. Sand content was negatively correlated with the concentrations of $\mathrm{Zn}$ $(\mathrm{r}=-0.78), \mathrm{Pb}(\mathrm{r}=-0.47), \mathrm{Cu}(\mathrm{r}=-0.85)$ and $\mathrm{Cr}(\mathrm{r}=-0.58)$ and the contents of silt and clay were positively correlated with $\mathrm{Zn}(\mathrm{r}=0.77$ and $\mathrm{r}=0.64), \mathrm{Cu}(\mathrm{r}=0.85$ and $r=0.73)$ and $\mathrm{Cr}(\mathrm{r}=0.53$ and $\mathrm{r}=0.62)$ in the $\alpha=0.05$ (Table 5). As emphasized by Kocowicz (2000), the knowledge of soil particle size leads to the conclusion about its origin, as well as it provides the information about other features, such as susceptibility to erosion or reactions to pollution.

Heavy metals are non-biodegradable and may persist in the environment long enough to diminish soil quality and to be taken up by plants and included in the food chain, posing a major threat to soil quality and biodiversity (Fuentes et al. 2004). However, heavy metals may be transported by plants from below ground tissues to above tissues and then can accumulate in leaves and stems. The degree of upward translation depends on not only the species of plant and the nature of metal, but also on a number of environmental conditions (Paraíba and Kataguiri 2008). According to McGeer et al. (2003), the process of substance accumulation in an organism in relation to the substance concentration in the external medium is called bioconcentration. The bioconcentration factor $(B C F)$ is defined as the substance partition coefficient between the organism and the external medium, i.e. it is calculated as the quotient between the organism and the external medium sub- stance concentrations. Therefore, the $B C F$ describes the organism substance accumulative potential or the organism substance bioconcentration in a specific medium (Kabata-Pendias and Pendias 1999). Bioconcentration factor $(B C F)$ in this study allowed for estimating the ability of plants to collect heavy metals present in the soil. It reflects the speed and volume of movement of metals from the soil solution with the addition of different doses of sewage sludge to the aerial parts of plants (Table 6).

Based on these results, it was found that the rate of bioconcentration of $\mathrm{Cd}$, $\mathrm{Cr}, \mathrm{Cu}$ and $\mathrm{Pb}$ was the highest in August, which may indicate the ease of downloading these metals by plants, particularly high mobility of metals during this period, and lower in October and June (Table 6). Authors observed that chromium was a metal with the highest bioconcentration potential and lead - with the lowest. The highest and lowest value of the $B C F$ for chromium were recorded at the fertilization with a dose of $15 \mathrm{~kg} / \mathrm{m}^{2}$ for Eko and Roadside grass mixtures, respectively 4.89 and 0.67 . According to Singh and Agrawal (2008), toxicity of heavy metals largely depends on their features and they may cause physiological and anatomical changes in plants (Perronnet et al. 2000). Prasad obtained similar results (2004), discussing the negative impact of metals present in the cell for such processes, as photosynthesis, respiration and transpiration.

Although zinc and copper are among the elements which carry a high risk of a chemical imbalance in the biosphere, as they have a high ability to accumulate in the environment and there are ones of the most mobile metals in the soil 
TABLE 6. Bioconcentration factors of heavy metals in lawn grasses mixtures depending on the dose of sewage sludge and harvest time

\begin{tabular}{|c|c|c|c|c|c|c|c|c|c|c|}
\hline \multirow{4}{*}{$\begin{array}{l}\text { Heavy } \\
\text { metals }\end{array}$} & \multirow{4}{*}{$\begin{array}{l}\text { Months } \\
\text { of harvest }\end{array}$} & & & Grass & ixtures & & & \multirow{4}{*}{ Means } & \multirow{4}{*}{$\begin{array}{l}\text { Standard } \\
\text { deviation }\end{array}$} & \multirow{4}{*}{$n$} \\
\hline & & & Eko & & & oadsi & & & & \\
\hline & & \multicolumn{6}{|c|}{ dose of sewage sludge $\left(\mathrm{kg} / \mathrm{m}^{2}\right)$} & & & \\
\hline & & 0.0 & 7.5 & 15.0 & 0.0 & 7.5 & 15.0 & & & \\
\hline \multirow{3}{*}{$\mathrm{Cd}$} & June & 0.27 & 0.26 & 0.09 & 0.22 & 0.23 & 0.80 & 0.31 & 0.51 & 72 \\
\hline & August & 1.67 & 2.31 & 1.48 & 2.26 & 1.69 & 1.65 & 1.84 & 1.10 & 72 \\
\hline & October & 0.69 & 0.67 & 0.34 & 0.30 & 0.29 & 0.75 & 0.51 & 0.51 & 72 \\
\hline \multirow{3}{*}{$\mathrm{Cr}$} & June & 2.76 & 2.27 & 4.13 & 2.67 & 1.41 & 1.89 & 2.52 & 3.86 & 72 \\
\hline & August & 4.09 & 3.13 & 4.89 & 3.59 & 1.93 & 2.33 & 3.33 & 4.20 & 72 \\
\hline & October & 1.51 & 1.30 & 2.14 & 1.59 & 0.81 & 0.67 & 1.34 & 1.34 & 72 \\
\hline \multirow{3}{*}{$\mathrm{Cu}$} & June & 0.63 & 0.69 & 0.67 & 0.70 & 0.66 & 0.64 & 0.66 & 0.24 & 72 \\
\hline & August & 0.67 & 0.87 & 0.79 & 0.76 & 0.69 & 0.71 & 0.75 & 0.29 & 72 \\
\hline & October & 0.51 & 0.65 & 0.55 & 0.68 & 0.56 & 0.60 & 0.59 & 0.16 & 72 \\
\hline \multirow{3}{*}{$\mathrm{Pb}$} & June & 0.13 & 0.15 & 0.19 & 0.15 & 0.20 & 0.17 & 0.17 & 0.09 & 72 \\
\hline & August & 0.34 & 0.28 & 0.22 & 0.21 & 0.26 & 0.25 & 0.26 & 0.12 & 72 \\
\hline & October & 0.09 & 0.12 & 0.04 & 0.10 & 0.08 & 0.06 & 0.08 & 0.07 & 72 \\
\hline \multirow{3}{*}{$\mathrm{Zn}$} & June & 1.08 & 1.30 & 1.00 & 1.04 & 0.84 & 0.86 & 1.02 & 0.63 & 72 \\
\hline & August & 0.83 & 1.08 & 1.15 & 0.85 & 0.88 & 0.93 & 0.95 & 0.52 & 72 \\
\hline & October & 0.77 & 0.84 & 0.84 & 0.84 & 0.68 & 0.77 & 0.79 & 0.41 & 72 \\
\hline
\end{tabular}

(Dmuchowski and Sołtykiewicz 2007). The applied mixtures of grasses (Roadside and Eko) and fertilization with sewage sludge did not affect the bioconcentration factors of zinc and copper in the aerial parts of plants and $B C F$ index ranged from 0.68 to 1.30 for zinc and from 0.51 to 0.87 for copper during the vegetation period (Table 6). As pointed by Lequeux et al. (2010), most of copper after absorption is kept in roots causing the damage to cell membranes, a change of their liquidity and their semi-permeable features, which in the first stage is seen as the outflow of cell electrolytes from the cells, among others potassium ions, and in the end results in the disturbance of the whole cell metabolism.
The lubricants used in cars may be a source of $\mathrm{Cd}$ contamination of lawns along the roads. The urban areas and areas adjacent to the busy traffic routes are the most vulnerable to pollution. The threat posed by emissions from motor vehicles is greater because their toxic components are released into the atmosphere, often in densely populated areas where the buildings reduces the natural exchange of air (Kabata-Pendias and Pendias 1999, Badyda 2010). In the case of cadmium, the highest value of $B C F$ was observed in the plots where the Eko mixture was grown at fertilization with a dose of $7.5 \mathrm{~kg} / \mathrm{m}^{2}$ (2.31), while the lowest (0.22) was observed in June in the plots where the 
Roadside mixture was grown without fertilization (Table 6). As emphasized by Drążkiewicz et al. (2003), the rate of bioconcentration of various heavy metals, especially cadmium, is characterized by high species and even varietal diversity. Plants absorb metals from the soil solution mainly through the root system (Minkina et al. 2012), but they also absorb them from the atmosphere (e.g. in the area of communication pathways) through stomates and leaf surfaces in gaseous form or as dissolved metals in rainwater (Prasad 2004). Although cadmium is not required for plant growth, it is taken very easily, both through the roots and leaves, generally proportionally to the concentration in the environment (Stingu et al. 2011).

The accumulation of heavy metals by plants depends on various factors, such as soil physico-chemical properties, sewage sludge composition, sludge application rate, plant species, climatic factors, and chemical speciation of metals (Mahdy et al. 2007). The statistical analysis revealed significant correlations between the different metals in the studied soils. The total content of $\mathrm{Pb}$ in the soil was significantly correlated with the contents of $\mathrm{Zn}(\mathrm{r}=0.42)$ and $\mathrm{Cu}(\mathrm{r}=0.56)$, while $\mathrm{Cr}$ content was significantly correlated with the levels of $\mathrm{Zn}$ and $\mathrm{Cu}$ (respectively $\mathrm{r}=0.48$ and $\mathrm{r}=0.45)$ at $\mathrm{p} \leq 0.05$. There was also a significant correlation between the contents of $\mathrm{Zn}$ and $\mathrm{Cu}(\mathrm{r}=0.91)$ with $\alpha=0.05$. Moreover, there were significant correlations between concentrations of metals in soil and the metal content in the aerial parts of lawn grass mixtures. In presented study concentrations of $\mathrm{Cr}$ in the soil were significantly correlated with the concentrations of $\mathrm{Cd}(\mathrm{r}=0.51)$,
$\mathrm{Cu}(\mathrm{r}=0.61)$ and $\mathrm{Zn}(\mathrm{r}=0.57)$ in plant, while the concentration of $\mathrm{Zn}$ in soil were significantly correlated with concentration of $\mathrm{Cu}$ in plants $(\mathrm{r}=0.66)$ at $\mathrm{p} \leq 0.05$.

\section{CONCLUSIONS}

1. The dose of sewage sludge influenced heavily the development of turfness of urban lawns. Habitat conditions also influenced their development to lesser extent.

2. The dose of $7.5 \mathrm{~kg} / \mathrm{m}^{2}$ of sludge increased the size of the dry weight by $53 \%$ on average. On average the share of sown species amounted to $83 \%$ and it was higher than in control by $15 \%$ on average. Perennial ryegrass dominated among grass species. The share of alien species was reduced by $9 \%$ on average.

3. The sludge dose of $15 \mathrm{~kg} / \mathrm{m}^{2}$ increased dry weight of grasses by $90 \%$ on average. Among found plant species there was $87 \%$ sown species $(81 \%$ perennial ryegrass itself).

4. Fertilization with sediment resulted in more intensive development of perennial ryegrass and weaker development of Kentucky bluegrass in the foreign mixture (Roadside) than in the Polish one (Eko).

5. The concentration of $\mathrm{Cd}, \mathrm{Cu}, \mathrm{Cr}, \mathrm{Pb}$ and $\mathrm{Zn}$ in the surface layer of the soil is significantly correlated with the biomass of the above-ground parts, $\mathrm{pH}$ and the granulometric properties.

6. The bioconcentration factors of heavy metals in plants are characterized by considerable seasonal variation. The highest value of $\mathrm{Cd}, \mathrm{Cr}, \mathrm{Cu}$ and $\mathrm{Pb}$ bioconcentration was in August. 


\section{Acknowledgement}

This work was done with financial support of NCN, project N305 367438 .

\section{REFERENCES}

BADYDA A.J. 2010. Zagrożenia środowiskowe ze strony transportu. [Environmental impact of transport]. Nauka 4: 115-125 [Eng. Summary].

BREDE D. 2000: Turfgrass Maintenance Reduction Handbook: Sports, Lawns and Golf. Ann Arbor Press, Chelsea, Michigan, USA.

CLARKE B.O., SMITH S.R. 2011: Review of 'emerging' organic contaminants in biosolids and assessment of international research priorities for the agricultural use of biosolids. Environment International 37: 226-47.

CZARNECKI Z., HARKOT W. 2002: Wpływ częstotliwości koszenia na zadarnianie powierzchni przez trawnikowe odmiany Lollium perenne. [Effect of cutting frequency on surface sodding by lawn cultivars of Lollium perenne]. Łąkarstwo w Polsce 5: 43-48 [Eng. Summary].

Directive 2008/98/EC of the European Parliament and of the Council of 19 November 2008 on waste and repealing certain directives.

DMUCHOWSKI W., SOŁTYKIEWICZ E. 2007: Hiperakumulacja cynku w liściach brzozy brodawkowatej (Betula pendula Roth). [Zinc hyperacculation by silver birch (Betula pendula Roth) leaves]. Ochrona Środowiska i Zasobów Naturalnych 31: 209-214 [Eng. Summary].

DOMAŃSKI P.J., GOLIŃSKA B. 2003: Perspektywy Lolium perenne w użytkowaniu trawnikowym i darniowym. [Prospects for Lollium perenne in lawn and turf utilization]. Lakkarstwo w Polsce 6: 37-45 [Eng. Summary].

DRĄŻKIEWICZ M., TUKENDORF A., BASZYŃSKI T. 2003: Age-dependent response of maize leaf segments to cadmium treatment: Effect on chlorophyll fluorescence and phytochelation accumulation. Journal of Plant Physiology 160: 247-254.

FILIPKA T., KACZOR A., BADORA A. 2002: Podstawy i skutki chemizacji agroekosystemów. [Fundamentals and consequences of chemization of agroekosystems]. Akademia Rolnicza, Lublin [In Polish].
FUENTES A., LLORENS M., SAEZ J., SOLER A., AGUILAR M., ORTUNO F. 2004: Phytotoxicity and heavy metals speciation of stabilized sewage sludges. Journal of Hazardous Materials 108: 161-169.

GAWROŃSKI S.W. 2009: Fitoremediacja a tereny zieleni. [Phytoremediation and green areas]. Zieleń Miejska 10 (31): 28-29 [Eng. Summary].

GONDEK K. 2012: Wpływ nawożenia nawozami mineralnymi, obornikiem od trzody chlewnej i komunalnymi osadami ściekowymi na plon i niektóre wskaźniki jakości ziarna pszenicy jarej (Triticum aestivum L.). [The effect of fertilisation with mineral fertilisers, pig manure and municipal sewage sludge on the yield and some quality indices of spring wheat (Triticum aestivum L.) grain]. Acta Agrophysica 19 (2): 289-302 [Eng. Summary].

GRABOWSKI K., GRZEGORCZYK S., BENEDYCKI S., KWIETNIEWSKI H. 1999: Ocena wartości użytkowej wybranych gatunków i odmian traw gazonowych do obsiewu nawierzchni trawiastych. [Assessment of functional value of selected species and cultivars of lawn grasses for sowing of grass surface]. Folia Universitatis Agriculturae Stetinensis 197, Agricultura 75: 81-88 [Eng. Summary].

GREINERT A. 2000: Ochrona i rekultywacja terenów zurbanizowanych. Monografia 97. Wyd. Politechniki Zielonogórskiej, Zielona Góra.

JANKOWSKI K., SOSNOWSKI J., JANKOWSKA J., KOWALCZYK R. 2012: Zadarnienie muraw trawnikowych w zależności od głębokości umieszczenia hydrożelu w podłożu oraz rodzaju okrywy glebowej. [Impact of hydrogel and kind of soil cover on the compactness of turf lawns]. Inżynieria Ekologiczna 30: 249-256 [Eng. Summary].

KABATA-PENDIAS A., PENDIAS H. 1999: Biogeochemia pierwiastków śladowych. [Biogeochemistry of trace elements]. Państwowe Wydawnictwo Naukowe, Warszawa [In Polish].

KARCZEWSKAA., GERSZTYN L., GAŁKA B. 2012: Wpływ dodatku osadów ściekowych o różnych właściwościach na udział rozpuszczalnych form miedzi w glebach zanieczyszczonych. [The effects of various kinds of sewage sludge applied to soil on the amounts of soluble copper forms in polluted soils]. Ochro- 
na Środowiska i Zasobów Naturalnych 51: 53-61 [Eng. Summary].

KAZIMIERCZAK M. 2012: Sewage sludge stabilization indicators in aerobic digestion - a review. Ann. Warsaw Univ. Life Sci. - SGGW, Land Reclam. 44: 101-109 [Eng. Summary].

KOCOWICZ A. 2000: Zróżnicowanie składu granulometrycznego gleb Karkonoskiego Parku Narodowego. Opera Corcontica 37: 98-102.

LEQUEUX H., HERMANS CH., LUTTS S., VERBRUGGEN N. 2010: Response to copper excess in Arabidopsis thaliana: Impact on the root system architecture, hormone distribution, lignin accumulation and mineral profile. Plant Physiology and Biochemistry 48: 673-682.

MAHDY A.M., ELKHATIB E.A., FATHI N.O. 2007: Cadmium, copper, nickel, and lead availability in biosolids-amended alkaline soils. Australian Journal of Basic and Applied Sciences 1: 354-363.

McGEER J.C., BRIX K.V., SKEAFF J.M., DEFOREST D.K., BRIGHAM S.I., ADAMS W.J., GREEN A. 2003: Inverse relationship between bioconcentration factor and exposure concentration for metals: Implications for hazard assessment of metals in the aquatic environment. Environmental Toxicology and Chemistry 22, 5: 1017-1037.

MINKINA T.M., MOTUZOVA G.V., MANDZHIEVA S.S., NAZARENKO, O.G. 2012: Ecological resistance of the soil-plant system to contamination by heavy metals. Journal of Geochemical Exploration 123: 33-40.

OLSZEWSKA M., GRZEGORCZYK S., BAŁUCH-MAŁECKA A. 2008: Wymiana gazowa i indeks zieloności liści Trifolium repens uprawianej w mieszankach z Festulolium braunii i Lolium perenne w zależności od zróżnicowanego nawożenia azotem. [Gas exchange and leaf greenness in Trifolium repens grown in mixtures with Festulolium braunii and Lolium perenne depending on different nitrogen rates]. Ląkarstwo w Polsce 11: 147-156 [Eng. Summary].

PARAÍBA L.C., KATAGUIRI K. 2008: Model approach for estimating potato pesticide bioconcentration factor. Chemosphere 73: $1247-$ $-1252$.

PATHAK A., DASTIDAR M.G., SREEKRISHNAN T.R. 2009: Bioleaching of heavy metals from sewage sludge: A review. Journal of Environmental Management 90, 8: 2343-2353.
PAWLUŚKIEWICZ B. 2009: Analiza możliwości wykorzystania gazonowych odmian traw do poprawy powierzchni trawiastych na obszarach zurbanizowanych. [Analysis of possibilities of turf grass cultivars application or improvement of grass surface on urbanized areas]. Rozprawy naukowe i monografie. Wyd. SGGW, Warszawa [In Polish].

PERRONNET K., SCHWARTZ C.H., GERARD E., MOREL J.L. 2000: Availability of cadmium and zinc accumulated in the leaves of Thlaspi caerulescens incorporated into soil. Plant Soil 227: 257-263.

PN-ISO 11047:2001. Jakość gleby - Oznaczanie kadmu, chromu, kobaltu, miedzi, ołowiu, manganu, niklu i cynku w ekstraktach gleby wodą królewską. Metody płomieniowej i elektrotermicznej absorpcyjnej spektrometrii atomowej. [Soil quality. Determination of $\mathrm{Cd}, \mathrm{Cr}, \mathrm{Co}, \mathrm{Cu}$, $\mathrm{Pb}, \mathrm{Mn}, \mathrm{Ni}$ and $\mathrm{Zn}$ in extracts with aqua regia. Methods of flame and electrothermal atomic absorption spectroscopy]. Polski Komitet Normalizacyjny, Warszawa [In Polish].

PN-R-04032:1998. Gleby i utwory mineralne - Pobieranie próbek i oznaczanie składu granulometrycznego. [Soils and mineral grounds. Soil sampling and grain size distribution]. Polski Komitet Normalizacyjny, Warszawa [In Polish].

PRASAD M.N.V. 2004: Heavy metal stress in plants: from biomolecules to ecosystems. 2nd edn. Springer-Verlag, Berlin, Heidelberg.

RAJKUMAR M., NARASIMHA M., PRASAD V., SWAMINATHAN S., FREITAS H. 2013: Climate change driven plant-metal-microbe interactions. Environment International 53: 74-86.

RAPER L.R., JOHNSON C.E. 1995: Prediction of soil stresses beneath a rigid wheel. Journal of Agriculture Engineering Research 61: 57-62.

Rozporządzenie Ministra Środowiska z dnia 13 lipca 2010 r. w sprawie komunalnych osadów ściekowych. [Directive of Environmental Minister of July 13th, 2010 concerning municipal sewage sludges]. Dz.U. 2010 nr 137, poz. 924 [In Polish].

SINGH R.P., AGRAWAL M. 2008: Potential benefits and risks of land application of sewage sludge. Waste Management 28: 347-358.

SIUTA J., WASIAK G. 2001: Zasady wykorzystania osadów ściekowych na cele nieprzemysłowe (przyrodnicze). [Principles of the use of 
sewage sludge for non-industrial purposes]. Inżynieria Ekologiczna 3: 13-32 [Eng. Summary].

STARCK Z. 2006: Różnorodne funkcje węgla $i$ azotu w roślinach. [Multiple functions of carbon and nitrogen in plants]. Kosmos Problemy Nauk Biologicznych 55: 243-257.

STINGU A., STANESCU I., VOLF I., POPA V.I. 2011: Hyperaccumulation of cadmium in maize plant (Zea mays). Cellulose Chemistry and Technology 45: 287-290.

Streszczenie: Wpływ osadu ściekowego na wzrost i sktad gatunkowy runi oraz na zawartość metali ciężkich $w$ roślinach i glebie. Celem badań było określenie wpływu nawożenia komunalnym osadem ściekowym z Miejskiej Oczyszczalni Ścieków w Sokółce na wzrost i skład gatunkowy runi trawników przyulicznych oraz zawartość metali w częściach nadziemnych tych roślin. Badania przeprowadzono na czterech powierzchniach badawczych, wzdłuż głównych ciagów komunikacyjnych na terenie Białegostoku. Zastosowano dwie mieszanki gazonowych odmian traw (Eko i Roadside) oraz trzy dawki osadu ściekowego: 0 (kontrola), 7,5 i $15 \mathrm{~kg} / \mathrm{m}^{2}$. Dawka 7,5 kg/m² zwiększyła masę części nadziemnych średnio o $53 \%$, a dawka $15 \mathrm{~kg} / \mathrm{m}^{2}$ - średnio o $90 \%$. Największy efekt nawożenia stwierdzono na glebie najlżejszej. W tych warunkach siedliskowych masa runi nawożonej dawką $15 \mathrm{~kg} / \mathrm{m}^{2}$ osadu była prawie dwukrotnie, a dawką $7,5 \mathrm{~kg} / \mathrm{m}^{2}$ prawie $58 \%$ większa niż na powierzchniach nienawożonych. Gatunkiem dominującym w runi badanych po- wierzchni była życica trwała (Lolium perenne L.). Stanowiła ona w masie runi na powierzchniach nawożonych dawką $7,5 \mathrm{~kg} / \mathrm{m}^{2}$ średnio $71 \%$, dawką $15 \mathrm{~kg} / \mathrm{m}^{2}$ - średnio $81 \%$, a na powierzchniach nienawożonych - średnio 50\%. Wartość wskaźnika biokoncentracji $\mathrm{Cd}, \mathrm{Cr}, \mathrm{Cu}$ i $\mathrm{Pb}$ była największa w sierpniu, co może świadczyć o łatwości pobierania tych metali przez rośliny i szczególnie dużej ruchliwości metali w tym okresie, najmniejsza natomiast w październiku oraz czerwcu.

Stowa kluczowe: wykorzystanie osadów ściekowych, gazonowe odmiany traw, biomasa, tereny przydrożne

\section{MS. received in May 2014}

\section{Authors' addresses:}

Elżbieta Wołejko

Zakład Biologii Sanitarnej i Biotechnologii

Wydział Budownictwa i Inżynierii Środowiska

Politechnika Białostocka

ul. Wiejska 45E

15-351 Białystok, Poland

e-mail: elzbietawolejko@wp.pl

Bogumiła Pawluśkiewicz

Katedra Kształtowania Środowiska

Wydział Budownictwa i Inżynierii Środowiska SGGW

ul. Nowoursynowska 159

02-776 Warszawa, Poland

e-mail: bogumila_pawluskiewicz@sggw.pl 